\title{
Insights From the Implementation and Adoption of Community-Based Health Interventions
}

\author{
Amans Ntakarutimana, MEng \\ University of Rwanda, Kigali, Rwanda \\ (iD https://orcid.org/0000-0001-5014-5011 \\ Jeanne N. Kagwiza, PhD \\ University of Rwanda, Kigali, Rwanda \\ (iD) https://orcid.org/0000-0002-8546-5047
}

Emmy Bushaija, MSc

University of Rwanda, Kigali, Rwanda

(iD) https://orcid.org/0000-0002-4337-5019

David K. Tumusiime, $\mathrm{PhD}$

University of Rwanda, Kigali, Rwanda

(iD https://orcid.org/0000-0003-3855-6795

Nelson Ekane, $\mathrm{PhD}$

Stockholm Environment Institute, Stockholm, Sweden

(iD https://orcid.org/0000-0002-9340-4391

Kristin A. Schuller, $\mathrm{PhD}$

Ohio University, Athens, Ohio, United States

(iD) https://orcid.org/0000-0001-5692-6054

Contact: ntamans1@gmail.com

\section{Abstract}

Effective implementation of health interventions is critical for maximum adoption and optimal health outcomes. This qualitative study assessed the differences in Community Health Club (CHC) implementation in villages using qualitative research methods. Villages in Rusizi district in Rwanda were purposively selected with high, medium, and low adoption rates. The results revealed that the traits and skills of intervention facilitators (providers or implementers) at the village level, the involvement of the head of the village in the $\mathrm{CHC}$ intervention activities, and the support supervision by the Community Environmental Health Officer from the health center may have contributed to high rates of adoption of the intervention. Poor community organization, mistrust, lack of equal consideration among intervention beneficiaries, and lack of skills and capacity for intervention facilitators may have contributed to the low rates of intervention adoption. The results of this study suggest the need for capacity building of implementers, local leaders, and supervisors for improved (1) skills to adapt to local contexts and maximize the intervention adoption, (2) involvement and

Note: We have no known conflict of interest to disclose. Correspondence concerning this article should be addressed to Amans Ntakarutimana, School of Health Sciences, College of Medicine and Health Sciences, University of Rwanda, 
participation of local leadership, and (3) support supervision, guidance, and close monitoring, respectively, for effective implementation and maximum adoption of $\mathrm{CHC}$ intervention.

Keywords: Community health club intervention, Households, Facilitators, Adoption, Limitations

Date Submitted: June 5, 2020 | Date Published: February 16, 2021

\section{Recommended Citation}

Ntakarutimana, A., Kagwiza, J. N., Bushaija, E., Tumusiime, D. K., Ekane, N., Schuller, K. A. (2021). Insights from the implementation and adoption of community-based health interventions. Journal of Social, Behavioral, and Health Sciences, 15, 61-75. https://doi.org/10.5590/JSBHS.2021.15.1.04

\section{Introduction}

Community health interventions fail to achieve the expected health outcomes due to their low adoption at the community level, which is not often considered in both implementation and evaluation (Koelen et al., 2001; Proctor et al., 2011). Adoption ("up take") of an intervention consists of behavioral change results that lead to full use of an innovation, which may consist of an idea, a practice, or an object and may be known as an intervention product (Rogers, 1983). The adoption of an intervention constitutes an intermediate outcome and serves as an indicator of implementation success or an indicator of the quality of the implementation of a health intervention (Carlfjord et al., 2010; Proctor et al., 2011). The lack of adoption of health interventions in a targeted community can serve as an access barrier, which ultimately reduces the benefits of the intervention's expected health outcome (Jeffries et al., 2017). The Rwanda Ministry of Health (RMoH) implemented the Community Health Club (CHC) intervention to educate households through their representatives on water sanitation and hygiene (WASH) and nutrition practices countrywide for the control of WASH-related diseases and malnutrition $(\mathrm{RMoH}, 2010)$. The adoption of the CHC intervention by households is measured by the percentage of households that completed all WASH and nutrition recommended practices of the intervention divided by the households reached by the intervention.

The implementation process of the $\mathrm{CHC}$ intervention consisted of how the intervention was implemented at the village level (Stoutenberg et al., 2018). The CHC intervention products include WASH and nutrition knowledge, behavior, and practices that the intervention intends to transfer. In contrast, diffusion of the intervention products consists of phases of disseminating the intervention and its products to communities for households to adopt them (diffusion of innovation; Durlak \& DuPre, 2008). The CHC intervention is implemented at the village level and comprised of household representatives organized into groups of 50 to 100 "clubs." Each club meets once a week for 2 hours for health education on WASH-related disease and malnutrition control and consensus on WASH and nutrition practices (recommended practices) to implement in their respective households. The community health worker, with an elected committee from the households' representatives, facilitated the health education for at least six months. Gradually, each of the household representatives, back in his/her home, worked with household members to implement the recommended practices while the village Community Health Worker (CHW), the CHC intervention committee, the head of the village, and the Community Environmental Health Officer (CEHO) from the health center serving the area monitored the households implementing the recommended WASH and nutrition practices. At the end of the six months, households that implemented all the recommended practices received a certificate of completion (RMoH, 2010; Waterkeyn \& Cairncross, 2005). Waterkeyn et al. (2019 and 2020) evaluated the adoption of the CHC intervention in 50 villages in Rusizi district and found different levels of adoption (adoption rate) varying from the highest, $93 \%$, to the lowest, $11 \%$ of adoption of the intervention by households.

The framework of effective implementation (Durlak and DuPre, 2008), the Reach, Effectiveness, Adoption, Implementation, and Maintenance (RE-AIM) framework dimensions (Glasgow \& Estabrooks, 2018), and the Diffusion of Innovations theory (Rogers, 1983; Dearing \& Cox, 2018) identified some factors that have 
influenced separately or together the effective implementation of community health interventions. Those factors include the community context; the target audience; the marketing appeals; the diffusion of innovations to maximize the intervention adoption; the provider characteristics, including skills and leadership capacity; the level of involvement, participation, support, supervision, and monitoring by the local leadership; and the delivery system. The National Academies of Sciences, Engineering, and Medicine (NASEM, 2017) suggest that identifying trusted implementation leaders is fundamental to effective implementation of community health interventions because it helps build, establish, and maintain trust in the community on one hand. On the other hand, implementation leaders with leadership skills and compassiondriven flexibility ensure skilled and trusted facilitators, community board or patient leadership, health literacy, and integrated locally based strategies and solutions for maximum intervention adoption and health effect (Durlak \& DuPre, 2008; NASEM, 2017). According to NASEM (2017), equity and legal (administrative) aspects, patient activation/motivation, access to finances for social and health needs, rewarding intervention adopters, assistance to vulnerable or marginalized people, case management, and patient-level support, including counseling, integrated care, and referral, are critical to effective implementation of community health intervention.

This study assessed the differences in the implementation process of the CHC intervention using the framework of effective implementation (Durlak \& DuPre, 2008) and the RE-AIM framework dimensions (Stoutenberg et al., 2018) among three villages, with their levels of adoption classified under low, medium and high adoption. Three main aspects of effective implementation of health intervention guided our assessment, including (1) the target audience and the intervention products defined as "innovation" delivered to beneficiaries, (2) how the intervention products were delivered for beneficiaries adoption, including delivery and support system, and (3) the beneficiaries' appreciation of the influencing factors of intervention adoption (Day et al., 2019; Durlak \& DuPre, 2008; NASEM, 2017 and RMoH, 2010). The results of the present study may inform the effective implementation process of the CHC intervention for its maximum adoption by households in the study area and similar regions (Durlak \& DuPre, 2008; Jeffries et al., 2017; Sijbesma \& Christoffers, 2009).

\section{Methods}

\section{Study Area and Study Design}

By 2017, 43.5\% of 15,000 villages in Rwanda had running CHCs. In Rusizi district, an evaluation conducted on 50 CHC intervention villages reported various levels of adoption of the $\mathrm{CHC}$ intervention by village households (RMoH, 2017). The present study was conducted in Rusizi district of Rwanda and targeted the same 50 villages that were exposed to the $\mathrm{CHC}$ intervention to improve water sanitation hygiene and nutrition practices at the household level under the RMoH Community-Based Environmental Health Promotion Program. The intervention was conducted without providing tangible materials to the community to improve water and sanitation. The intervention provided only training through 24 dialogue sessions and recommended practices as planned by the original $\mathrm{CHC}$ intervention design. Therefore, the 50 experimental villages were termed "classic" CHC villages. This study used a qualitative formative research design to better understand the implementation process of the $\mathrm{CHC}$ intervention among villages with different levels of adoption (low, medium, and high) in Rusizi district.

\section{The Intervention and Study Objective}

The CHC intervention has three parts: (1) a 6-month health education program that educates households' representatives on WASH-related disease and nutrition in weekly sessions, (2) application of recommended WASH and nutrition practices in respective households, and (3) monitoring of household practices through household visits by respective CHWs and village intervention committees ( $\mathrm{RMoH}, 2010)$. The respective 
heads of villages and CEHOs from health centers serving the area supervised the CHC intervention implementation (RMoH, 2010 and 2017). Due to limited evidence on the possible causes of the differences in the $\mathrm{CHC}$ intervention adoption across beneficiary villages in Rusizi district, the present study assessed the implementation process of the $\mathrm{CHC}$ intervention to get insights to inform the implementation process for improved household adoption of the CHC intervention and optimize health outcomes.

\section{Study Design, Questions, and Variables}

The study consisted of a cross-sectional qualitative study. To conduct focus group discussions, we used the implementation plan of the $\mathrm{CHC}$ intervention by the $\mathrm{RMoH}$ (2010) and the framework of effective implementation (Day et al., 2019; Durlak \& DuPre, 2008). The following questions were asked:

Describe the target audience and the products delivered under the $\mathrm{CHC}$ intervention to beneficiaries (the innovation).

- What was the target audience (beneficiaries)?

- What were the topics covered from CHC dialogue sessions and discussions (products)?

- What were the recommended behavior change and practices in your respective homes from CHC (innovation)?

- What were the $\mathrm{CHC}$ recommended facilities in your respective homes (indicators of monitoring)?

Describe how the intervention products were delivered to beneficiaries for adoption, including system support.

- What were the channels of communication?

- What did the facilitators do to mobilize and involve the target audience for the intervention adoption?

- Which role did the local/village leadership play in CHC implementation?

- To what extent did health professionals influence the $\mathrm{CHC}$ activities?

- Identify the beneficiaries' reported influencing factors on the adoption of the intervention.

- What were the limiting factors to the adoption of $\mathrm{CHC}$ intervention?

- What were the favoring factors to the adoption of $\mathrm{CHC}$ intervention?

The questions were pretested with the supervisors of the $\mathrm{CHC}$ intervention and validated based on the local context of the $\mathrm{CHC}$ implementation. The variables include the responses to the questions, which have been coded, categorized, and put into themes, based on the $\mathrm{CHC}$ intervention plan from $\mathrm{RMoH}$ (2010) and the framework of effective implementation (Day et al., 2019; Durlak \& DuPre, 2008). 


\section{Study Population, Sample Size, and Sampling Strategy}

From 50 villages that received the classic CHC intervention under the partnership of the Ministry of Health, Rusizi district, and Africa Applied Health Education and Development as the main development partner, 46 villages were classified according to their respective adoption levels ranging from $11 \%$ to $93 \%$. The adoption of $\mathrm{CHC}$ intervention by village households is measured based on graduation at the end of the six months of training. Therefore, the level of $\mathrm{CHC}$ intervention adoption per village is the number of households that graduated divided by the total households reached per village (depicted as a percentage). From the respective village $\mathrm{CHC}$ intervention adoption levels, we calculated the population mean and the standard deviation and obtained $\mu=52.28$ and $\delta=21.956$, respectively. We divided the population into three classes of adoption levels: medium ( 28 village CHCs $\mu-1 \delta<\mathrm{X}<\mu+1 \delta$ ), low (9 village CHCs $\mathrm{X} \leq \mu-1 \delta$ ), and high (9 village CHCs $\mathrm{X} \geq \mu+1 \delta$ ). In these formulas, $\mathrm{X}$ stands for adoption rate, $\mu$ for population mean, and $\delta$ for standard deviation. A purposive sampling was applied and within each adoption level, we simply picked one CHC village for data collection. The three selected CHC villages were Kamina for the high adoption class (93\% adoption rate), Kibare for the medium adoption class (50\% adoption rate), and Gataramo for the low adoption class (23\% adoption rate). From each village, we randomly selected 10 representatives of registered household beneficiaries of the $\mathrm{CHC}$ intervention from the list in the registration book of the village $\mathrm{CHW}$ and invited them to participate in the focus group interview. At each group we added the head of each village to have a focus group of 11 participants from each of the three villages.

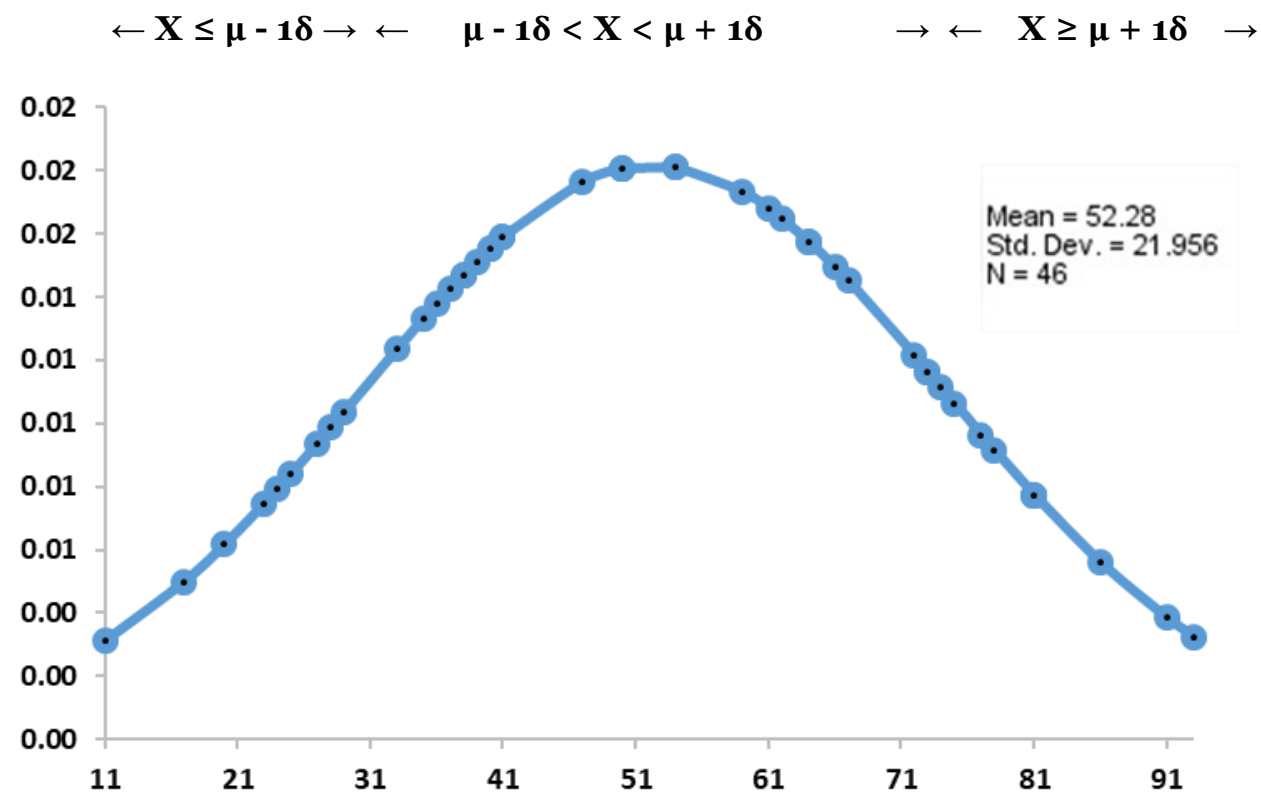

Figure 1. Variation of the Frequency of Adoption of the CHC Intervention

Table 1: Distribution of Classic CHC Villages According to Their Levels of Adoption

\begin{tabular}{lccc}
\hline Number of CHCs around the population mean \pm 1 standard deviation & \\
\hline Range & $\mathrm{X} \leq \mu-1 \delta$ & $\mu-1 \delta<\mathrm{X}<\mu+1 \delta$ & $\mathrm{X} \geq \mu+1 \delta$ \\
Number of CHCs & 9 & 28 & 9 \\
\hline
\end{tabular}




\section{Description of Study Villages and Study Participants}

The description of the study villages presented in Table 2 shows that the three villages were benefiting from similar ongoing interventions and activities in relation to WASH and nutrition practices pre CHC intervention. Post $\mathrm{CHC}$ intervention, the study villages have different levels of adoption of the CHC intervention. The study participants are representatives of households reached by the CHC intervention and include men, women, and the head of the village, making one group of participants per village for focus group interviews.

Table 2: Description of the Study Villages

\begin{tabular}{|c|c|c|c|}
\hline Villages & Kamina & Kibare & Gataramo \\
\hline \multirow{4}{*}{$\begin{array}{l}\text { Ongoing interventions in } \\
\text { villages pre } \mathrm{CHC} \\
\text { intervention }\end{array}$} & Parents evening, & Parents evening, & Parents evening, \\
\hline & Village kitchen & Village kitchen & Village kitchen \\
\hline & $\begin{array}{l}\text { Village council and } \\
\text { human security } \\
\text { meetings }\end{array}$ & $\begin{array}{l}\text { Village council and } \\
\text { human security } \\
\text { meetings }\end{array}$ & $\begin{array}{l}\text { Village council and } \\
\text { human security } \\
\text { meetings }\end{array}$ \\
\hline & $\begin{array}{c}\text { Community health } \\
\text { workers' interventions }\end{array}$ & $\begin{array}{c}\text { Community health } \\
\text { workers' interventions }\end{array}$ & $\begin{array}{c}\text { Community health } \\
\text { workers' interventions }\end{array}$ \\
\hline $\begin{array}{l}\text { Number of households } \\
\text { reached = intervention } \\
\text { coverage }\end{array}$ & 86 & 76 & 107 \\
\hline $\begin{array}{l}\text { Number of households that } \\
\text { graduated (that adopted the } \\
\text { intervention) }\end{array}$ & 80 & 38 & 25 \\
\hline Intervention adoption rate & $93 \%$ & $50 \%$ & $23 \%$ \\
\hline \multirow{4}{*}{$\begin{array}{l}\text { Composition of the focus } \\
\text { group interview } \\
\text { participants per village }\end{array}$} & 1 head of village & 1 head of village & 1 head of village \\
\hline & 4 men & 5 men & 4 men \\
\hline & 6 women & 5 women & 6 women \\
\hline & 11 & 11 & 11 \\
\hline
\end{tabular}

\section{Data Collection, Analysis, and Results}

The data collection consisted of audio-taped focus group interviews later transcribed. The transcripts produced were cleaned and coded by three people, each using the CHC intervention implementation plan with (1) the defined target audience for the intervention, (2) the health education topics planned for the intervention, (3) the activities planned during the implementation of $\mathrm{CHC}$ intervention, (4) the recommended behavior and practices for beneficiaries, (5) the recommended facilities in homes of beneficiaries, and (6) the supporting role of village leader and health center. The coding was harmonized to reduce bias (Ay et al., 2019; $\mathrm{RMoH}, 2010$ ). In plenary session, the codes were put into categories and later in themes using both an inductive and deductive approach based on the CHC intervention plan from RMoH (2010), the framework of effective implementation (Day et al., 2019; Durlak \& DuPre, 2008 ) and the principles of the implementation process of a public health campaign (NASEM, 2017). The data analysis results per codes, categories, and themes are presented in Table 3 below. 
Table 3: Data Analysis Results Per Codes, Categories, and Themes

\begin{tabular}{|c|c|c|c|c|c|}
\hline \multirow{2}{*}{$\begin{array}{l}\text { Focus group } \\
\text { interview } \\
\text { guiding } \\
\text { questions }\end{array}$} & \multicolumn{3}{|c|}{ Codes from the responses to questions per Community Health Club Village } & \multirow[t]{2}{*}{ Categories } & \multirow[t]{2}{*}{ Themes } \\
\hline & $\begin{array}{l}\text { Kamina village (93\% of } \\
\text { CHC adoption) }\end{array}$ & $\begin{array}{l}\text { Kibare village (50\% of CHC } \\
\text { adoption) }\end{array}$ & $\begin{array}{l}\text { Gataramo village (23\% of } \\
\text { CHC adoption) }\end{array}$ & & \\
\hline \multicolumn{6}{|c|}{ Target audience and the $\mathrm{CHC}$ intervention products delivered to the beneficiaries } \\
\hline $\begin{array}{l}\text { What was the } \\
\text { target audience? } \\
\text { Beneficiaries }\end{array}$ & $\begin{array}{l}\text { The primary beneficiaries } \\
\text { are households' } \\
\text { representatives in the } \\
\text { village who later teach their } \\
\text { respective entire household } \\
\text { members }\end{array}$ & $\begin{array}{l}\text { The primary beneficiaries are } \\
\text { households' representatives in } \\
\text { the village who later teach } \\
\text { their respective entire } \\
\text { household members }\end{array}$ & $\begin{array}{l}\text { The primary beneficiaries } \\
\text { are households' } \\
\text { representatives in the } \\
\text { village who later teach their } \\
\text { respective entire household } \\
\text { members }\end{array}$ & $\begin{array}{l}\text { Target } \\
\text { audience }\end{array}$ & $\begin{array}{l}\text { Target } \\
\text { audience }\end{array}$ \\
\hline $\begin{array}{l}\text { What were the } \\
\text { topics covered } \\
\text { from CHC } \\
\text { dialogue } \\
\text { sessions and } \\
\text { discussions? }\end{array}$ & $\begin{array}{l}\text { Malnutrition, Diarrhea, } \\
\text { Skin diseases, Worms, } \\
\text { Respiratory diseases, } \\
\text { Malaria and Bilharzia, } \\
\text { village needs assessment } \\
\text { Water Sources for domestic } \\
\text { use, Safe Drinking Water, } \\
\text { household Sanitation, } \\
\text { Personal Hygiene, } \\
\text { Handwashing, Food } \\
\text { Hygiene, } \\
\text { Infant Care, Good } \\
\text { Parenting, Nutrition, Food } \\
\text { Security }\end{array}$ & $\begin{array}{l}\text { Malnutrition, Diarrhea, } \\
\text { Skin diseases, Worms, } \\
\text { Respiratory diseases, Malaria } \\
\text { and Bilharzia, village needs } \\
\text { assessment } \\
\text { Water Sources for domestic } \\
\text { use, Safe Drinking Water, } \\
\text { household Sanitation, } \\
\text { Personal Hygiene, } \\
\text { Handwashing, Food Hygiene, } \\
\text { Infant Care, Good Parenting, } \\
\text { Nutrition, Food Security }\end{array}$ & $\begin{array}{l}\text { Malnutrition, Diarrhea, } \\
\text { Skin diseases, Worms, } \\
\text { Respiratory diseases, } \\
\text { Malaria and Bilharzia, } \\
\text { village needs assessment } \\
\text { Water Sources for domestic } \\
\text { use, Safe Drinking Water, } \\
\text { household Sanitation, } \\
\text { Personal Hygiene, } \\
\text { Handwashing, Food } \\
\text { Hygiene, } \\
\text { Infant Care, Good } \\
\text { Parenting, Nutrition, Food } \\
\text { Security }\end{array}$ & $\begin{array}{l}\text { WASH- } \\
\text { related } \\
\text { diseases and } \\
\text { malnutrition } \\
\text { Health } \\
\text { Needs } \\
\text { assessment } \\
\text { WASH } \\
\text { practices } \\
\text { Childcare } \\
\text { practices } \\
\text { Nutrition } \\
\text { practices }\end{array}$ & $\begin{array}{l}\text { Knowledge on } \\
\text { control of } \\
\text { WASH-related } \\
\text { diseases } \\
\text { Malnutrition }\end{array}$ \\
\hline $\begin{array}{l}\text { What were the } \\
\text { recommended } \\
\text { behavior change } \\
\text { and practices in } \\
\text { your respective } \\
\text { homes from } \\
\text { CHC? }\end{array}$ & $\begin{array}{l}\text { Covered and treated water, } \\
\text { clean drinking water } \\
\text { container, use of ladle and } \\
\text { individual cups for drinking } \\
\text { water, Use of Clean Water } \\
\text { Source, Clean-up of water } \\
\text { source, Rubbish } \\
\text { management, Zero Open } \\
\text { Defecation, clean yard, } \\
\text { compost and recycle pits, }\end{array}$ & $\begin{array}{l}\text { Covered and treated water, } \\
\text { clean drinking water } \\
\text { container, use of ladle and } \\
\text { individual cups for drinking } \\
\text { water, Use of Clean Water } \\
\text { Source, Clean-up of water } \\
\text { source, Rubbish management, } \\
\text { Zero Open Defecation, clean } \\
\text { yard, compost and recycle } \\
\text { pits, Washing clothes and }\end{array}$ & $\begin{array}{l}\text { Covered and treated water, } \\
\text { clean drinking water } \\
\text { container, use of ladle and } \\
\text { individual cups for drinking } \\
\text { water, Use of Clean Water } \\
\text { Source, Clean-up of water } \\
\text { source, Rubbish } \\
\text { management, Zero Open } \\
\text { Defecation, clean yard, } \\
\text { compost and recycle pits, }\end{array}$ & $\begin{array}{l}\text { Safe water } \\
\text { practices } \\
\text { Sanitation } \\
\text { behavior } \\
\text { and } \\
\text { practices } \\
\text { Hygiene } \\
\text { behavior }\end{array}$ & $\begin{array}{l}\text { Application of } \\
\text { the control } \\
\text { WASH-related } \\
\text { diseases and } \\
\text { malnutrition }\end{array}$ \\
\hline
\end{tabular}




\begin{tabular}{|c|c|c|c|c|c|}
\hline & $\begin{array}{l}\text { Washing clothes and } \\
\text { blankets, handwashing at } \\
\text { critical times, Pot rack and } \\
\text { hanging baskets, Individual } \\
\text { plates and shelves, wear } \\
\text { self-protective equipment } \\
\text { including shoes, } \\
\text { Immunization, making } \\
\text { SSS/ORS, Treatment of } \\
\text { skin diseases, Growth } \\
\text { monitoring card, medical } \\
\text { insurance, Exclusive } \\
\text { breastfeeding, balanced } \\
\text { diet, village saving and loan }\end{array}$ & $\begin{array}{l}\text { blankets, handwashing at } \\
\text { critical times, Pot rack and } \\
\text { hanging baskets, Individual } \\
\text { plates and shelves, wear self- } \\
\text { protective equipment } \\
\text { including shoes, } \\
\text { Immunization, making } \\
\text { SSS/ORS, Treatment of skin } \\
\text { diseases, Growth monitoring } \\
\text { card, medical insurance, } \\
\text { exclusive breastfeeding, } \\
\text { balanced diet, village saving } \\
\text { and loan }\end{array}$ & $\begin{array}{l}\text { Washing clothes and } \\
\text { blankets, handwashing at } \\
\text { critical times, Pot rack and } \\
\text { hanging baskets, Individual } \\
\text { plates and shelves, wear } \\
\text { self-protective equipment } \\
\text { including shoes, } \\
\text { Immunization, making } \\
\text { SSS/ORS, Treatment of skin } \\
\text { diseases, Growth } \\
\text { monitoring card, medical } \\
\text { insurance, exclusive } \\
\text { breastfeeding, balanced } \\
\text { diet, village saving and loan }\end{array}$ & $\begin{array}{l}\text { and } \\
\text { practices } \\
\text { Childcare } \\
\text { practices } \\
\text { Nutrition } \\
\text { practices } \\
\text { Access to } \\
\text { finance }\end{array}$ & \\
\hline $\begin{array}{l}\text { What were the } \\
\text { CHC } \\
\text { recommended } \\
\text { facilities in your } \\
\text { respective } \\
\text { homes? }\end{array}$ & $\begin{array}{l}\text { Functional hand wash } \\
\text { facility, Pot rack and } \\
\text { hanging baskets, improved } \\
\text { Clean Latrine, compost pit, } \\
\text { bath shelter, drying rope, } \\
\text { clean and covered drinking } \\
\text { water container, Kitchen } \\
\text { garden }\end{array}$ & $\begin{array}{l}\text { Functional hand wash facility, } \\
\text { Pot rack and hanging baskets, } \\
\text { improved Clean Latrine, } \\
\text { compost pit, bath shelter, } \\
\text { drying rope, clean and covered } \\
\text { drinking water container, } \\
\text { Kitchen garden }\end{array}$ & $\begin{array}{l}\text { hand wash facility, Pot rack, } \\
\text { improved Clean Latrine, } \\
\text { compost pit, bath shelter, } \\
\text { drying rope, clean and } \\
\text { covered drinking water } \\
\text { container, Kitchen garden }\end{array}$ & $\begin{array}{l}\text { WASH } \\
\text { facilities } \\
\text { Nutrition- } \\
\text { related } \\
\text { facility }\end{array}$ & \\
\hline \multicolumn{6}{|c|}{ How were the intervention products and system support delivered? } \\
\hline $\begin{array}{l}\text { What were the } \\
\text { channels of } \\
\text { communication? }\end{array}$ & $\begin{array}{l}\text { Weekly meeting of } 2 \text { hours } \\
\text { with presentations, } \\
\text { dialogue, discussions and } \\
\text { consensus, images, songs, } \\
\text { slogans }\end{array}$ & $\begin{array}{l}\text { Weekly meeting of } 2 \text { hours } \\
\text { with presentations, dialogue, } \\
\text { discussions and consensus, } \\
\text { images, songs, slogans }\end{array}$ & $\begin{array}{l}\text { Weekly meeting of } 2 \text { hours } \\
\text { with presentations, } \\
\text { dialogue, discussions and } \\
\text { consensus, images, songs, } \\
\text { slogans }\end{array}$ & $\begin{array}{l}\text { Meetings } \\
\text { Rational } \\
\text { appeal } \\
\text { Emotional } \\
\text { appeal }\end{array}$ & \multirow[t]{2}{*}{$\begin{array}{l}\text { Involvement } \\
\text { process of the } \\
\text { target } \\
\text { audience for } \\
\text { intervention } \\
\text { adoption }\end{array}$} \\
\hline $\begin{array}{l}\text { What the } \\
\text { facilitators did } \\
\text { to mobilize and } \\
\text { involve the } \\
\text { target audience } \\
\text { for the } \\
\text { intervention } \\
\text { adoption? }\end{array}$ & $\begin{array}{l}\text { Joint community } \\
\text { assessment with head of } \\
\text { village CHWs and } \\
\text { household representatives } \\
\text { CHC weekly meetings with } \\
\text { presentations and } \\
\text { discussions } \\
\text { Competition and } \\
\text { graduation ceremony } \\
\text { activities }\end{array}$ & $\begin{array}{l}\text { Joint community assessment } \\
\text { with CHWs and household } \\
\text { representatives } \\
\text { CHC weekly meetings with } \\
\text { presentations and discussions } \\
\text { Competition and graduation } \\
\text { ceremony activities }\end{array}$ & $\begin{array}{l}\text { Joint community } \\
\text { assessment with CHWs and } \\
\text { household representatives } \\
\text { CHC weekly meetings with } \\
\text { presentations and } \\
\text { discussions } \\
\text { Competition and graduation } \\
\text { ceremony activities }\end{array}$ & $\begin{array}{l}\text { Mobilization } \\
\text { of the target } \\
\text { audience }\end{array}$ & \\
\hline
\end{tabular}




\begin{tabular}{|c|c|c|c|c|}
\hline & $\begin{array}{l}\text { CHC savings and loan fund } \\
\text { with a weekly contribution } \\
\text { of } 100 \text { Rfw ( } \$ \text { O.1) per CHC } \\
\text { member to facilitate access } \\
\text { to finance for } \\
\text { recommended practices, } \\
\text { common unity and self- } \\
\text { development. } \\
\text { Promoting early adopters } \\
\text { for role models to be } \\
\text { advisors and supporters of } \\
\text { other CHC members } \\
\text { Skilled and early adopters } \\
\text { CHC member volunteered } \\
\text { to make "Step and wash" } \\
\text { (handwashing facility) and } \\
\text { support other CHC } \\
\text { members } \\
\text { Vulnerable CHC members } \\
\text { were assisted by community } \\
\text { work of the CHC members } \\
\text { to build latrines and by the } \\
\text { financial contribution of the } \\
\text { CHC members to get } \\
\text { matless and school fees for } \\
\text { their children }\end{array}$ & $\begin{array}{l}\text { CHC savings and loan fund } \\
\text { with a weekly contribution of } \\
1000 \mathrm{Rfw}(\$ 1) \text { per CHC } \\
\text { member to facilitate access to } \\
\text { finance for recommended } \\
\text { practices }\end{array}$ & $\begin{array}{l}\text { CHC savings and loan fund } \\
\text { with a weekly contribution } \\
\text { of } 100 \text { Rfw ( } \$ 0.1) \text { per CHC } \\
\text { member to facilitate access } \\
\text { to finance for recommended } \\
\text { practices }\end{array}$ & $\begin{array}{l}\text { Diffusion of } \\
\text { innovation }\end{array}$ \\
\hline $\begin{array}{l}\text { Which role did } \\
\text { the local/village } \\
\text { leadership play } \\
\text { in CHC } \\
\text { implementation }\end{array}$ & $\begin{array}{l}\text { Communiqué on CHC } \\
\text { meetings and schedule } \\
\text { The village leader was part } \\
\text { of the CHC members }\end{array}$ & $\begin{array}{l}\text { Communiqué on CHC } \\
\text { meetings and schedule } \\
\text { Visits of the village leader to } \\
\text { CHC activities sometimes }\end{array}$ & $\begin{array}{l}\text { Communiqué on CHC } \\
\text { meetings and schedule } \\
\text { Visits of the village leader to } \\
\text { CHC activities sometimes }\end{array}$ & $\begin{array}{l}\text { Involvement } \\
\text { of village } \\
\text { leadership }\end{array}$ \\
\hline $\begin{array}{l}\text { To what extent } \\
\text { health } \\
\text { professionals } \\
\text { influenced the } \\
\text { CHC activities? }\end{array}$ & $\begin{array}{l}6 \text { visits by the in-charge } \\
\text { health professional to } \mathrm{CHC} \\
\text { meetings }\end{array}$ & $\begin{array}{l}2 \text { visits by the in-charge health } \\
\text { professional to } \mathrm{CHC} \text { meetings }\end{array}$ & $\begin{array}{l}1 \text { visit by the in-charge } \\
\text { health professional to } \mathrm{CHC} \\
\text { meetings }\end{array}$ & $\begin{array}{l}\text { Supervision } \\
\text { and } \\
\text { monitoring } \\
\text { by the } \\
\text { health } \\
\text { center }\end{array}$ \\
\hline
\end{tabular}


Ntakarutimana et al., 2021

\begin{tabular}{|c|c|c|c|c|c|}
\hline $\begin{array}{l}\text { What were the } \\
\text { limiting factors } \\
\text { to the adoption } \\
\text { of CHC } \\
\text { intervention }\end{array}$ & $\begin{array}{l}\text { Some people need more } \\
\text { time to complete the } \\
\text { recommended practices } \\
\text { (CHC intervention } \\
\text { adoption) }\end{array}$ & $\begin{array}{l}\text { Mistrust of CHC facilitators } \\
\text { and CHC committee who lack } \\
\text { skills to make CHC activities } \\
\text { interesting (motivation) } \\
\text { Weekly contribution fixed at } \\
\text { 10oo Rfw ( } \$ 1 \text { ) per CHC } \\
\text { member for CHC savings and } \\
\text { loan fund discouraged poor } \\
\text { households and left the } \\
\text { intervention }\end{array}$ & $\begin{array}{l}\text { Poor village organization, } \\
\text { lack of submission of village } \\
\text { habitants to community } \\
\text { guiding rules and local } \\
\text { leadership prior CHC } \\
\text { intervention delayed } \\
\text { households joining to adopt } \\
\text { the intervention (complete } \\
\text { recommended practices = } \\
\text { healthy practices) }\end{array}$ & $\begin{array}{l}\text { Limiting } \\
\text { factors }\end{array}$ & $\begin{array}{l}\text { Influencing } \\
\text { factors of the } \\
\text { adoption of } \\
\text { the CHC } \\
\text { intervention }\end{array}$ \\
\hline $\begin{array}{l}\text { What were the } \\
\text { favoring factors } \\
\text { to the adoption } \\
\text { of CHC } \\
\text { intervention }\end{array}$ & $\begin{array}{l}\text { Trusted facilitator and CHC } \\
\text { committee, well organized } \\
\text { CHC, common unity in all } \\
\text { the activities, influence of } \\
\text { the village leadership }\end{array}$ & $\begin{array}{l}\text { Only wealthy households } \\
\text { adhered to CHC intervention's } \\
\text { activities }\end{array}$ & $\begin{array}{l}\text { CHC intervention has been } \\
\text { a starting point for a good } \\
\text { organization for the village. }\end{array}$ & $\begin{array}{l}\text { Favoring } \\
\text { factors }\end{array}$ & \\
\hline
\end{tabular}

The study results show the CHC intervention targeted the same audience and provided the same products to the targeted audience. The difference is observed at the level of (1) how the intervention products were delivered (system delivery), and (2) system support for the CHC intervention adoption, and (3) the study participants highlighted the limiting and favoring factors of the CHC intervention adoption. 


\section{Discussion}

Although the implementation of CHC intervention targeted the same audience and provided the same products focused on (1) knowledge on the control of WASH-related diseases and malnutrition, and (2) application of the control of WASH-related diseases and malnutrition, including WASH and nutrition-related behavior, practices, and facilities in participating households, the delivery system and the support system varied at some points. According to the study participants, the limiting and favoring factors of the CHC intervention adoption were associated with local organization context, level of trust, capacity of CHW and committee, ingredients for increased intervention adoption, and time for complete behavior change.

\section{The Delivery System}

The three villages benefited from the same products, having almost identical channels of communication as per the CHC intervention plan. These products include the topics covered during the weekly dialogue sessions and discussions, the recommended behavior change, and practices for the control of WASH-related disease and malnutrition. The channel of communication used consisted of weekly two-hour meetings with presentations, dialogue, discussions, and consensus (rational appeal) with slogans, songs (emotional appeal) for at least six months. Mutual assistance and assistance to the vulnerable were reported in all three villages, and Kamina, Kibare, and Gatamo focus groups later established a CHC savings and loan funds with each member making a weekly contribution of $\$ 0.10, \$ 1.00$, and $\$ 0.10$, respectively. In addition, the Kamina focus group interview showed that early adopters were recognized and together with skilled CHC members assisted with making "step and wash" (handwashing) facilities for all CHC members and built latrines for vulnerable households. These aspects are part of the diffusion of innovation strategies that are proven to positively influence the adoption of the intervention among the target audience (Dearing, 2009; Dearing \& Cox, 2018; Mahamed et al., 2012). Although all three villages demonstrated this "diffusion of innovation" during the implementation of the CHC intervention, it was much more apparent in the Kamina CHC, where they recognized and actively promoted "early adopters" as role models to help other CHC members complete the recommended practices.

\section{The Support System}

The support system aspects identified were comprised of the head of village participation in the intervention activities and the visits by the CEHO to the villages. These supports meant involvement, support supervision, and monitoring and were considered a motivating factor for intervention adoption. Kamina village was more privileged to have the head of the village serve as part of the $\mathrm{CHC}$ intervention as well as experiencing frequent visits by the CEHO, which did not happen for the Kibare and Gataramo villages.

\section{Reported Influencing Factors of the CHC Intervention Adoption}

The influencing factors included favoring factors and inhibiting factors of the CHC intervention adoption.

\section{Favoring factors}

In addition to diffusion of innovation strategies that were applied in all the three research villages, specific factors were identified to influence the $\mathrm{CHC}$ intervention adoption. In Kamina village, research participants confirmed (1) they trusted the CHC intervention facilitator and committee, (2) they were well organized during the CHC intervention, (3) they had unity in all the activities, and (4) ownership and the active participation of the head of village positively influenced the adoption of the CHC intervention. In Kibare and Gataramo villages, no favoring factor was reported. In Kamina village (93\% of CHC intervention adoption), early adopters and skilled CHC members assisted others with acquiring "step and wash" handwashing facilities and the village leader (head of village) owned and participated in CHC intervention activities more 
than in the other villages. The trust in the CHC intervention facilitator and committee and the established unity in Kamina village are reported to have favored the high rate of adoption, while in the other study intervention villages these were not reported.

\section{Inhibiting factors}

In Kibare village, with 50\% intervention adoption, research participants reported that the distrust of the $\mathrm{CHC}$ facilitator and committee, the weekly contribution (\$1) per CHC member for the saving and loan fund for the $\mathrm{CHC}$ members meant that the program was out of reach for low-income households and limited the adoption of the CHC intervention. In Gataramo (23\% adoption of the CHC intervention), poor village organization, lack of prior submission of village habitants to community guiding rules, and local leadership were reported as limiting factors to CHC intervention adoption. O’Mara-Eves et al. (2013) explained that community engagement for effective intervention outcomes is negatively affected by social exclusion, cost overrun, and dissatisfaction. Kenny et al. (2013) highlighted that the level of community participation for effective implementation of health intervention is affected by the skills capacity of intervention facilitators, the community organization, and the established mutual trust and respect, Meuter et al. (2015) pointed out that miscommunication affects the quality of working relationships between intervention providers and beneficiaries. This may account for the relatively low uptake in Kibare and Gataramo villages.

The reported favoring and inhibiting factors of the CHC intervention adoption suggest that the attitude and skills of CHC intervention facilitators, good organization, use of early adopters as models and mutual assistance, participation of and involvement of local leaders, and support supervision by the health center are potential for increased adoption of the CHC intervention (Dearing, 2009; Dearing \& Cox, 2018; Faridi et al., 2007; Mahamed et al., 2012). Therefore, capacity building for intervention providers (facilitators or implementers), local leaders, and supervisors from health centers is necessary for improved (1) skills to adapt to local contexts and maximize the intervention adoption, (2) involvement and participation of local leadership, and (3) support supervision, guidance, and close monitoring, respectively, for effective implementation and maximum $\mathrm{CHC}$ intervention adoption.

\section{Conclusion}

The diffusion of innovation with recognition of early adopters and skilled people to participate as role models in helping others, the aspect of mutual assistance and assistance to the vulnerable, the involvement of the head of the village in the CHC intervention activities, and the support supervision by the CEHO from the health center may have contributed to high levels of intervention adoption in Kamina village. On the other hand, poor community organization, mistrust, lack of equal consideration among intervention beneficiaries, and lack of skills and capacity of the intervention facilitators at the village level may have contributed to the low intervention adoption in Kibare and Gataramo villages. There is a need to be consistent with the diffusion of innovation while implementing $\mathrm{CHC}$ intervention. The capacity building for the implementers of CHC intervention, local leaders, and supervisors is needed for improved (1) skills to adapt to local context, (2) involvement and participation of local leadership, and (3) support supervision, guidance, and close monitoring for effective implementation and maximum intervention adoption. While the insights from the study results may help to increase the $\mathrm{CHC}$ intervention adoption in the study sites, there is a need to extend this research to other implementation sites to draw more generalizable conclusions. This will contribute in informing the implementation, monitoring, and evaluation of community health interventions. 
Ntakarutimana et al., 2021

\section{Study Limitations}

Other influencing factors may not have been documented during the focus group interview, which could have played the role of favoring or inhibiting adoption of the $\mathrm{CHC}$ intervention. Also, recall bias may have affected the results as study participants may have omitted some important details. 


\section{References}

Ay, P., Teker, A. G., Hidiroglu, S., Tepe, P., Surmen, A., Sili, U., Korten, V., \& Karavus, M. (2019). A qualitative study of hand hygiene compliance among health care workers in intensive care units. The Journal of Infection in Developing Countries, 13(2):111-117. https:/doi.org/10.3855/jidc.10926

Carlfjord, S., Lindberg, M., Bendtsen, P., Nilsen, P., \& Andersson, A. (2010). Key factors influencing adoption of an innovation in primary health care: A qualitative study based on implementation theory. BMC Family Practice, 11, 6o. https://doi.org/10.1186/1471-2296-11-6o

Day, R. E., Sahota, P., \& Christian, M. S. (2019). Effective implementation of primary school-based healthy lifestyle programmes: A qualitative study of views of school staff. BMC Public Health, 19, 1239. https://doi.org/10.1186/s12889-019-7550-2

Dearing J. W. (2009). Applying diffusion of innovation theory to intervention development. Research on Social Work Practice, 19(5), 503-518. https://doi.org/10.1177/1049731509335569\

Dearing, J. W., \& Cox, J. G. (2018). Diffusion of innovations theory, principles, and practice. Health Affairs (Millwood), 37(2), 183-190. https://doi.org/10.1377/hlthaff.2017.1104

Durlak, J. A., \& DuPre, E. P. (2008). Implementation matters: A review of research on the influence of implementation on program outcomes and the factors affecting implementation. American Journal of Community Psychology, 41, 327-350. https://doi.org/10.1007/s10464-008-9165-0

Faridi, Z., Grunbaum, J. A., Gray, B. S., Franks, A., \& Simoes, E. (2007). Community-based participatory research: Necessary next steps. Preventing Chronic Disease, 4(3), A70. http://www.cdc.gov/pcd/issues/2007/jul/o6 0182.htm

Glasgow, R. E., \& Estabrooks, P. E. (2018). Pragmatic applications of RE-AIM for health care initiatives in community and clinical Settings. Preventing Chronic Disease, 15, E02. https://doi.org/10.5888/pcd15.170271

Jeffries, M., Phipps, D. L., Howard, R. L., Avery, A. J., Rodgers, S., \& Ashcroft, D. M. (2017). Understanding the implementation and adoption of a technological intervention to improve medication safety in primary care: A realist evaluation. BMC Health Services Research, 17, 196. https://doi.org/10.1186/s12913-017-2131-5

Kenny, A., Hyett, N., Sawtell, J., Dickson-Swift, V., Farmer, J., \& O’Meara, P. (2013). Community participation in rural health: A scoping review. BMC Health Services Research, 13, 64. https://doi.org/10.1186/1472-6963-13-64

Koelen, M. A., Vaandrager, L., \& Colomer, C. (2001). Health promotion research: Dilemma and challenges. Journal of Epidemiological Community Health, 55, 257-262. https://www.ncbi.nlm.nih.gov/pmc/articles/PMC1731873/pdf/v055p00257.pdf

Mahamed, F., Parhizkar, S., \& Shirazi, A. R. (2012). Impact of family planning health education on the knowledge and attitude among Yasoujian women. Global Journal of Health Science, 4(2), 110-118. https:/doi.org/10.5539/gjhs.v4n2p110

Meuter R. F. I., Gallois, C., Segalowitz, N. S., Ryder, A. G., \& Hocking, J. (2015). Overcoming language barriers in healthcare: A protocol for investigating safe and effective communication when patients or clinicians use a second language. BMC Health Services Research, 15, 371. https://doi.org/10.1186/s12913-015-1024-8

National Academies of Sciences, Engineering, and Medicine. (2017). Health communication with immigrants, refugees, and migrant workers: Proceedings of a workshop-in brief. National Academies Press (US), PMID: 28586184 . 
O’Mara-Eves, A., Brunton, G., McDaid, D., Oliver, S., Kavanagh, J., Jamal, F., Matosevic, T., Harden, A., \& Thomas, J. (2013). Community engagement to reduce inequalities in health: A systematic review, meta-analysis and economic analysis. Public Health Research, 1(4), 111-121.

https://doi.org/10.3310/phro1040

Proctor, E., Silmere, H., Raghavan, R. Hovmand, P., Aarons, G., Bunger, A., Griffey, R., \& Hensley, M. (2011). Outcomes for implementation research: Conceptual distinctions, measurement challenges, and research agenda. Administration and Policy in Mental Health, 38(2), 65-76.

https://doi.org/10.1007/s10488-010-0319-7

Rogers, E. M. (1983). Diffusion of innovations. New York: Free Press.

Rwanda Ministry of Health (2010). Roadmap of Community Based Environmental Health Promotion Program. https://www.wsp.org/sites/wsp.org/files/publications/CBEHPP.pdf

Sijbesma, C., \& Christoffers, T. (2009). The value of hygiene promotion: Cost effectiveness analysis of interventions in developing countries. Health Policy and Planning, 24(6), 418-27. https:doi.org/10.1093/heapol/czpo36

Stoutenberg, M., Galaviz, K. I., Lobelo, F., Joy, E., Heath, G. W., Hutber, A., \& Estabrooks, P. (2018). A pragmatic application of the RE-AIM framework for evaluating the implementation of physical activity as a standard of care in health systems. Prevention of Chronic Diseases, 15, 170344. http://dx.doi.org/10.5888/pcd15.170344

Waterkeyn, J., \& Cairncross, S. (2005). Creating demand for sanitation and hygiene through Community Health Clubs: A cost-effective intervention in two districts in Zimbabwe. Social Science and Medicine, 61(9), 1958-1970. https://doi.org/10.1016/j.socscimed.2005.04.012

Waterkeyn, J. A. V., Matimati, R., Muringaniza, A., Chigono, A., Ntakarutimana, A., Katabarwa, J., Katabarwa, J., Bigirimana, Z., Pantoglou, J., \& Cairncross, S. (2019). Comparative assessment of hygiene behaviour change and cost-effectiveness of Community Health Clubs in Rwanda and Zimbabwe. IntechOpen. http://dx.doi.org/10.5772/intechopen.89995

Waterkeyn, J., Waterkeyn, A., Uwingabire, F., Pantoglou, J., Ntakarutimana, A., Mbirira, M., Katabarwa, J., Bigirimana, Z., Cairncross, S., \& Carter, R. (2020). The value of monitoring data in a process evaluation of hygiene behaviour change in Community Health Clubs to explain findings from a cluster-randomised controlled trial in Rwanda. BMC Public Health, 20, 98.

https://doi.org/10.1186/s12889-019-7991-7

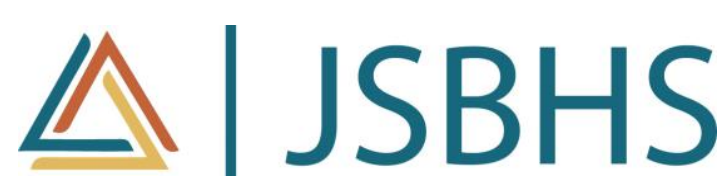

The Journal of Social, Behavioral, and Health Sciences (JSBHS), co-sponsored by the College of Health Sciences and the College of Social and Behavioral Sciences at Walden University, is a peer-reviewed, online, interdisciplinary journal focusing on theoretically-based research that addresses contemporary national and international issues. JSBHS articles include peer-reviewed research reports, brief reports, comprehensive literature reviews, books reviews, and student research. 